\title{
SURVIVING TRADITIONAL VILLAGE HERITAGE IN RAPID URBANIZATION: THE CASE OF KAJANG TOWN
}

\author{
Hafez Zainudin ${ }^{1}$ \\ Faculty of Creative Industries, \\ Universiti Tunku Abdul Rahman (UTAR), Malaysia. \\ (Email: hafez@utar.edu.my) \\ Aloysius Yapp ${ }^{2}$ \\ Centre for Immersive Technology and Creativity (CITC), \\ Universiti Tunku Abdul Rahman (UTAR), Malaysia. \\ (Email: aloysius@utar.edu.my)
}

Received date: $17-05-2019$

Revised date: 04-07-2019

Accepted date: 04-09-2019

Published date: 10-09-2019

To cite this document: Zainudin, H., \& Yapp, A. (2019). Surviving Traditional Village Heritage in Rapid Urbanization: The Case of Kajang Town. International Journal of Heritage, Art and Multimedia, 2(6), 33-40.

DOI: $10.35631 /$ ijham.26004

\begin{abstract}
The Greater Kuala Lumpur development initiative by the Malaysian government which began in 2010 has brought a tremendous economic benefits and opportunities for the people of Kuala Lumpur and its surrounding towns. However, this ambitious project has also altered the physical landscape of traditional villages in the neighbouring areas as well as the lifestyle of people affected. Kajang town is one of the smaller towns located in the outskirts of Kuala Lumpur city affected by the development. The purpose of this paper is to investigate the surviving and remaining cultural heritage among traditional village communities in Kajang and to identify the promising cultural heritage that can be preserved digitally. The study was focused on traditional cultural ceremonies which are still being practiced by communities in villages located along Jalan Cheras, which were directly affected by the Sungai Buloh-Kajang (SBK) MRT project which is apart of the Greater Kuala Lumpur development. This project has impacted the lifestyle and activities of the villagers and there are risks of cultural heritage loss among these communities. Qualitative research method was employed through discussions and interviews with the local community, village elders, local museum curator and through visits and observation of the remaining villages. The result suggests that some of the loss of natural heritage such as orchards and rivers have led to the loss of cultural heritage of villagers in ceremonial activities. However, there are also opportunities towards the preservation of the cultural heritage of Kajang villages through new media identified through this study, considering the positive support from youths towards cultural activities. The result acquired from this study will be used to further develop research work on digitization of tangible cultural heritage of this unique town.
\end{abstract}

Keywords: Village Heritage, Urban Development, Cultural Heritage, Kajang Town 


\section{Introduction}

In the past decades, the growth of the capital city of Kuala Lumpur and the surrounding Klang Valley has publicized a remarkable progress due to various development initiatives by the government to improve the economy and quality of life of the population within. The Greater Kuala Lumpur development initiative by the Malaysian government is part of the Economic Transformation Programme announced in 2010. One of the important components of the Greater Kuala Lumpur is the improvisation of transportation and mobility within the Klang Valley. The result will be cities, towns, and areas that link together into integrated regions, allowing for them to function as a single economic unit, leading to economies of scale and a far stronger distribution network - for goods, services, and information (Aziz, Kassim \& Masirin, 2018).

Hulu Langat is a district in southeast Selangor, and it is quietly booming. The constituency has Kajang as its centre of growth and this town may well be part of the Greater Kuala Lumpur conurbation (Singh, 2013). According to the 2010 National Census, Kajang is the third largest town in Malaysia based on the populations within the local government areas. By sheer population size Klang, Subang Jaya and Kajang ought to be considered cities. All these areas, though within Selangor, are themselves greatly varying in character, size, demography, ethnic makeup and culture (Yeoh, 2011).

Touted as a Greater Kuala Lumpur hotspot, Kajang has much to offer residents and developers alike as development plans for housing and better infrastructure are afoot by various parties (Singh, 2013). The purpose of this research is to investigate the surviving and remaining cultural heritage among traditional village communities in Kajang and to find out the possible cultural heritage that can be preserved, developed and offered (Aziz \& Abdullah, 2011). The study was focused on the villages and the kampong communities along Jalan Cheras, Kajang, areas which were directly affected by the Cheras-Kajang Expressway project in 1998 and the Sungai Buloh-Kajang (SBK) MRT project in 2017, which both are parts of the Greater Kuala Lumpur development. These projects have definitely altered the physical and cultural landscape of traditional villages in the neighbouring areas as well as the lifestyle of people affected.

\section{Literature Review}

The Kajang district covers an area of $787.61 \mathrm{~km} 2$ and it is surrounded by other smaller towns such as Cheras, Semenyih, Bangi, Putrajaya and Serdang. These towns serve as important economic, education and administrative centres. Along with other urban centres in Selangor with population of 150,000 and above in Peninsular Malaysia, historical factors had played a vital role in the growth of the economy and population (Hasan \& Nair, 2017). Despite the uniqueness that Kajang has to offer in terms of its heritage and history, little efforts were taken to preserve and conserve.

Choo (2014) quoted Singh (2013) in his report "There are no comprehensive books on Kajang's history or its development through the ages. There is not much initiative to preserve Kajang's heritage and many of these places will otherwise be knocked down and forgotten over time". According to Lee Kim Sin, director of the Kajang Heritage Centre and former Kajang assemblyman, the founding of the area can be traced back to the 1850s when the Javanese and Sumatrans lived in small pocket settlements along Sungai Langat (Khoo, 2018). 
Subsequently, in the 1870s, Chinese and Indian migrants moved to the area as labourers and traders (Khoo, 2018). Based on the study conducted by PLANMalaysia@Selangor in 2016, four traditional kampongs located within Kajang district which are Kampung Batu 10 Cheras, Kampung Bukit Dukung, Kampung Sungai Jernih and Kampung Sungai Ramal Luar has been in existence for more than 100 years.

Sadly, some of these kampongs have been partially demolished and significant numbers of villagers were forced to move to a different housing area (Figure 1). The annexation of these rural settlements located near the metropolitan areas has contributed to acceleration of the urbanisation process (Hasan \& Nair, 2017). This wave of demolishing the urban villages, which were commonly regarded by government officials and urban planners as the "cancer" of the city has provoked a lot of attention and public debate on issues of fairness, equity, and justice with regard to the villagers, and motivated many people to self-consciously document and preserve in various ways memories of these urban villages ( $\mathrm{Yu}, 2017)$. The unique historical development of states still has an important and inter-related influence on the urbanisation process (Hasan \& Nair, 2017). As kampongs physically as tangible cultural heritage disappear, the intangible heritage of the inhabitants will disappear simultaneously.

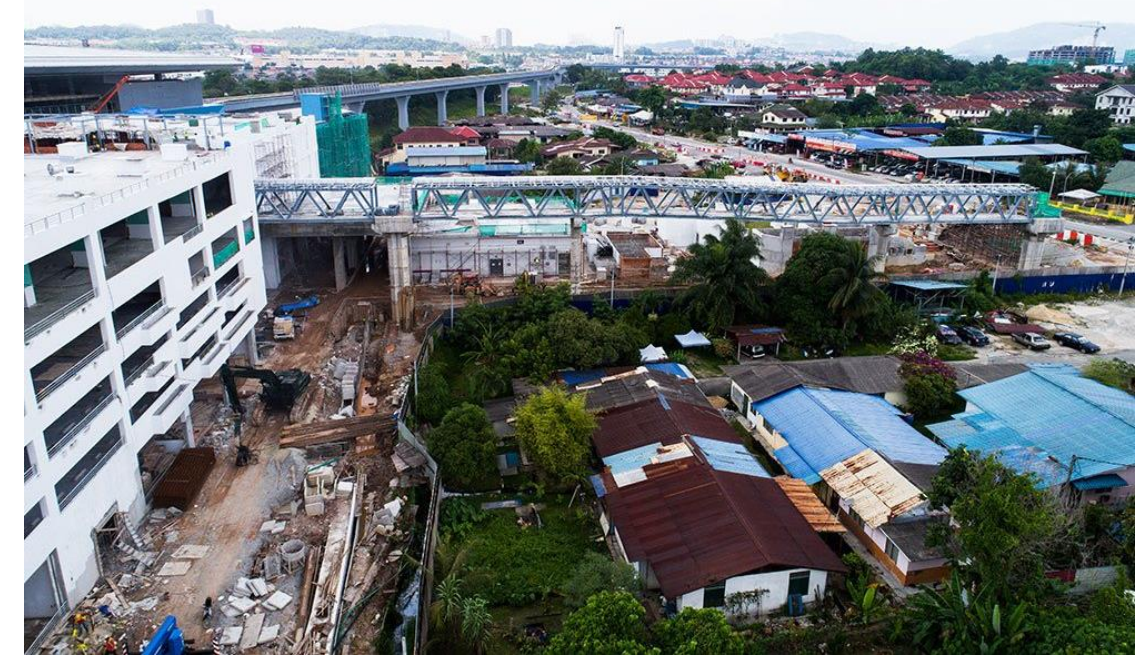

Figure 1: MRT Station Being Built Alongside the Remaining Village of Kampung Bukit Dukung at Jalan Cheras, Kajang in 2017

Source: https://www.bigkl.com/mrt/bukit-dukung-mrt-station 


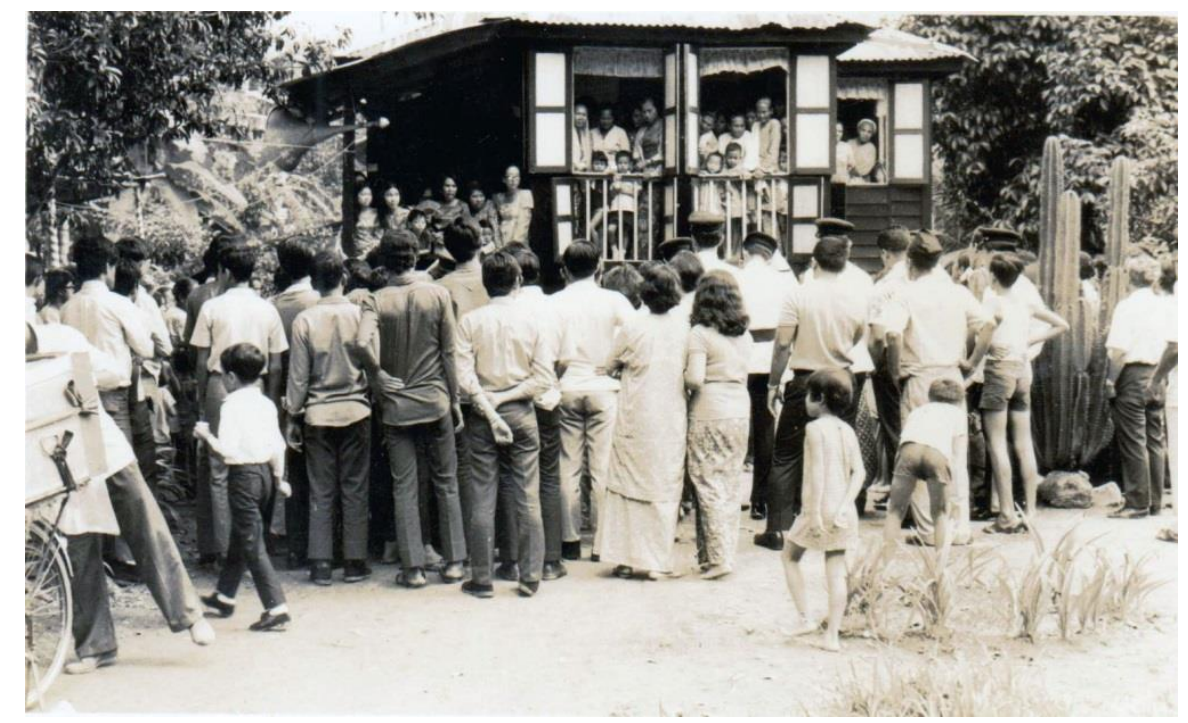

Figure 2: A Scene of a Traditional Malay Wedding at Kampung Batu 12, Kajang in 1960s.

Source: Personal Collection.

\section{Methodology}

In performing this research, the researchers work towards answers by selecting small geographical area as the subject and investigate contemporary real-life phenomenon through analysis of a limited number of events. The information gained mostly comprised of opinion based on facts, supporting data, information and objective evidences (Bachek, Zainudin \& Haron, 2014). The study was focused on traditional cultural ceremonies which are still being practiced by communities in kampongs located along Jalan Cheras, Kajang.

In obtaining primary data the researchers conducted a series of in-depth interviews with local community leaders, village elders, a local museum curator, photographic records and observation of the remaining kampongs. For convenience all the informants were interviewed on-site. This is to allow the researchers the opportunity to follow up on some of the informants' responses related to their respective community (Rahimah, 2017). Understandings gained about village urbanism and the history and heritage of Kajang town from secondary data were accumulated and compared with the findings from the observations and interviews. Through the observations conducted on this area, evidences of ceremonial cultural activities can be seen. The intangible culture recognized through ceremonial activities that are commonly practiced in villages within the study area has been analyzed.

\section{Findings}

Kajang community was made of a various ethnic and sub-ethnic group through migrations centuries ago. The Langat River was very significant in the formation of Kajang town. According to Singh (2013), the Langat River was one such highway that brought travellers to the hinterland of Selangor. It was also along the Langat River that the settlement of Kajang started. Main kampongs and settlements in Kajang were named after rivers (sungai); Kampung Sungai Sekamat, Kampung Sungai Balak, Kampung Sungai Jernih, Kampung Sungai Kantan, Kampung Sungai Ramal, Sungai Jelok, Kampung Sungai Merab and Sungai Chua. Back in the 1960s, in traditional Malay kampongs, there used to be seasonal fishing activities and villagers would gather to take part and festive-like scenario. Today, most of these rivers are heavily polluted, unhygienic and unusable for any kind of activity. Besides that, based on the interviews conducted with kampong elders, it was found out that the loss of 
natural heritage has led to the loss of some of the cultural heritage of the villages. Villagers used to own orchards and it was easy to acquire raw materials to be crafted and used in cultural ceremonies. With more lands are being sold or acquired by government and developers, these raw materials are getting harder to find. Although traditional kampong ceremonies such as wedding, engagement and circumcision are still being practiced today, they are not visually the same as it was 40 to 50 years ago.

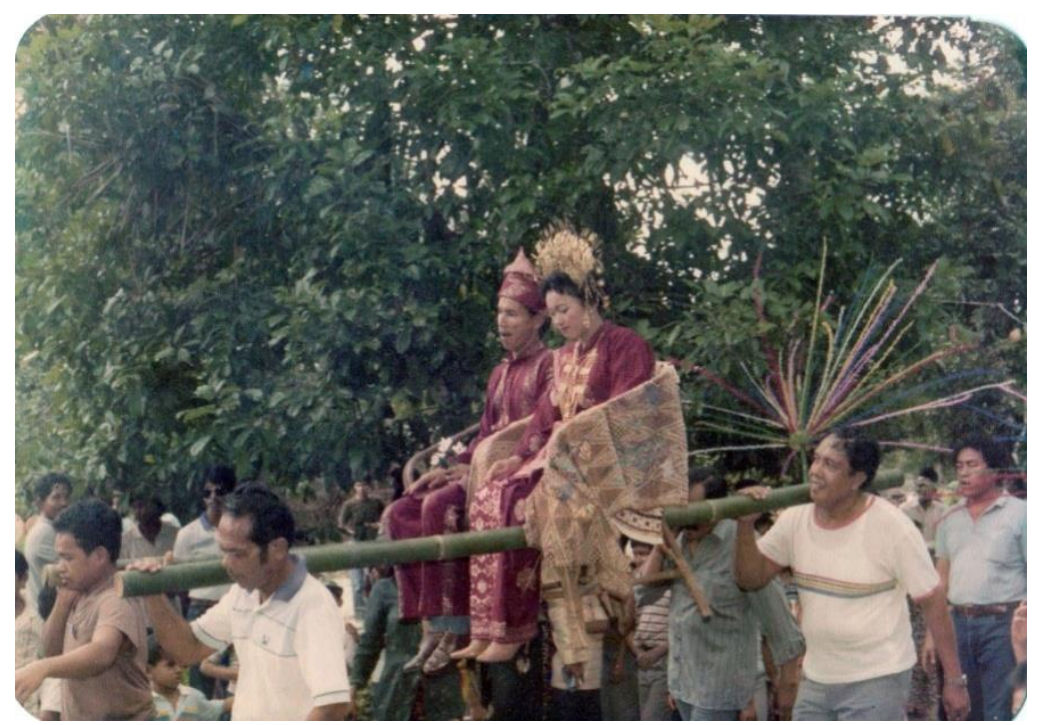

Figure 3: Traditional Ceremony of Upholding the Bride and Groom using Bamboo Carrier in a Malay Wedding in late 1970s.

Source: Personal Collection.

One of the uniqueness of Kajang kampong heritage relating to ceremonial activities is the Sukmo Rogo silat performance. Literally means "Soul and Body",this martial art was originated from Java, Indonesia and was established in Kajang since 1925 by the late master Mr.Sukimin Bin Marto. Today, in its third generation the silat is still being widely practiced within villages in Kajang. The silat comes with its own uniqueness in term of the movements, clothing, rituals and music being used compared to other forms of silat. It is common to see the silat being performed in wedding ceremonies and other cultural related events around Kajang and it is popular among youngsters, teenagers and children with more than 1000 registered members across Kajang area. 


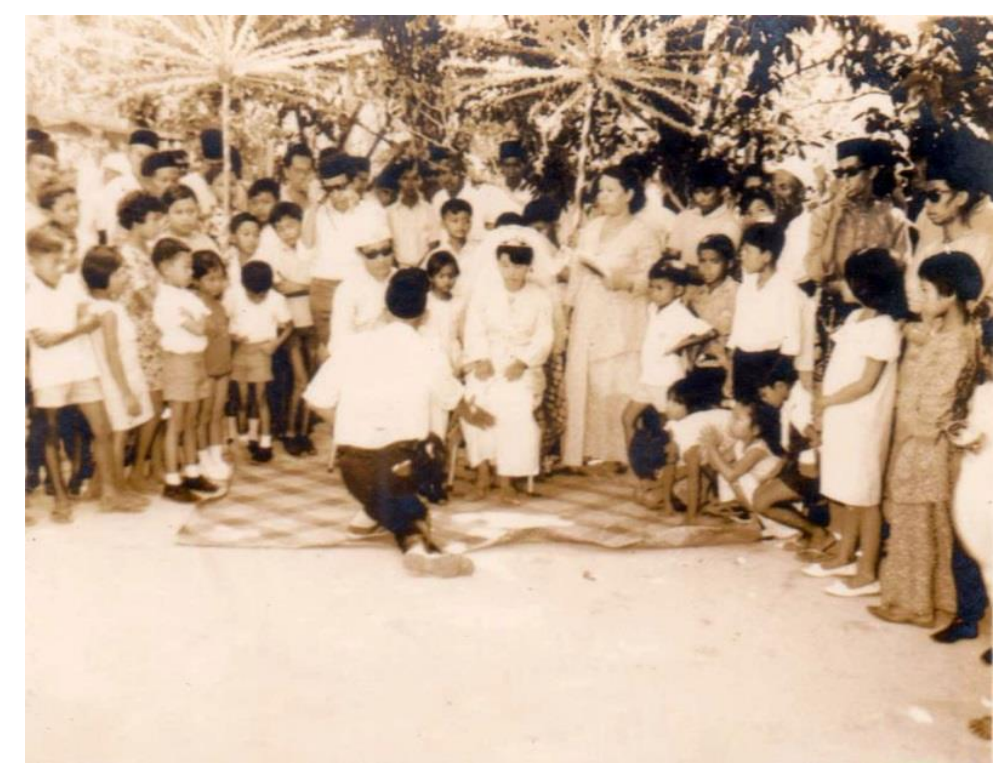

Figure 4: The Sukmo Rogo Silat Performance during a Wedding Ceremony in 1960s. Source: Personal Collection.

Interview analysis and site observations conducted in this research as per recommended by Rahimah (2017) have been focused on intangible cultural heritage of the Kajang kampong community. The findings from SWOT analysis that has been made include:

-The Strengths

The socio-culture of Kajang village showed some promising future through the villagers' activities. Participation from younger generation in cultural happenings within Kajang societies is very positive and the acceptance towards the idea of digitization of Kajang town's own heritage is very encouraging. Efforts taken by the Kajang Heritage Centre has managed to somewhat popularize heritage tourism in Kajang and further inspire participations and collaboration with universities and local community.

-The Weaknesses

The loss of natural heritage such as rivers and vegetation through urban development and pollution has caused some rituals and traditional cultural activities to disappear completely and became unknown to the younger generation.

-The Opportunities

Kajang cultural distinctiveness will hopefully grow into creating its own sense of place to be remembered. Various cultural artefacts belonging to various sub-ethnic groups with high heritage values are still available for digital preservation. Sukmo Rogo martial arts and performance has great potential to be developed and promoted as local cultural heritage by looking through their activeness, popularity in cultural events and ceremonies in Kajang. Through active participation and contribution by villagers, local tourism will be very likely to become successful. Community-based tourism (CBT) refers to tourism that involves community participation and aims to generate benefits for local communities in the developing world by allowing tourists to visit these communities and learn about their culture and the local environment (Supriharjo, Rahmawati, Santoso, Setiawan \& Pradinie, 2016). 
-The Threats

Considering the location of Kajang town as the hot spot of the Greater Kula Lumpur, migration of new population may further alter the socio-cultural landscape of the local communities. Besides that, extensive unnecessary future modernization works will cause the town to lose its authenticity and the natural atmosphere of kampongs in Kajang would be threatened with the rapid development.

\section{Conclusion}

There are needs to give greater attention to aspects of community involvement in urban conservation alongside contemporary development that have changed the tangible and intangible heritage of historical towns. The cultural heritage of Kajang is worth preserving and it has to be promoted based on the various sub-ethnic groups living in the town as a whole, as these communities moved themselves together in building the town's history and heritage.

The direction of this research is towards the digitization of the history and cultural heritage of Kajang town through potential new media such as Virtual Reality, animation and digital scanning to preserve tangible and intangible heritage of this unique town and its multi ethnic community. This may include the creation of virtual museum or gallery to enable a more immersive and interactive experience for visitors or tourists. Through the success of other towns in Malaysia such as Georgetown in Penang and Ipoh in Perak in promoting heritage tourism, a lot can be learnt through different programmes and networking with relevant parties from the heritage and conservation activists and community. Penang has successfully painted itself as a cosmopolitan city of heritage, culinary delights, culture and history which in turn has been a catalyst for city transformation through a multitude of stakeholders (Hasan \& Nair, 2017).Findings and data obtained from this study will be very important for the researchers to include in the next level of research on the digital preservation of the heritage of Kajang town.

\section{References}

Aziz, K. A., \& Abdullah, F. Z. (2011). Cultural Heritage Tourism Development in Kota Lama Kanan, Kuala Kangsar, Perak. Universiti Tun Abdul Razak E-Journal, 7(2).

Aziz, R. A. (2017). Heritage Conservation: Authenticity and Vulnerability of Living Heritage sites in Melaka State. Kajian Malaysia, 35, 39-58.

Aziz, S. A., Kassim, R. \&Masirin, M. I. M. (2018). Railway Development and the Impact to Malaysian Economy.Journal of Advance Research in Dynamical \& Control Systems, 10(6).

Bachek, S. H., Zainudin, H. \& Haron, N. A. (2014). Preservation of Culture and Built Heritage in New Urban Development: A Case Study on Little India Brickfields, Kuala Lumpur. International Proceedings of Economics Development and Research, 74, 1.

Chen, S. (2017). Toward Multiple Conceptions of the Human-Nature Relationship: The"Human-Nature Unity" Frame in a Chinese Village. International Journal of Communication (19328036), 11.

Choo, W. L. (2014, Dec 2). Penning Down the Past. The Star Online. Retrieved from https://www.thestar.com.my

Ellisa, E. (2016). Coping with Crowding in High-Density Kampung Housing of Jakarta. International Journal of Architectural Research: ArchNet-IJAR, 10(1), 195-212.

Hasan, A. R., \& Nair, P. L. (2017). Urbanisation and Growth of Metropolitan Centres in Malaysia. Malaysian Journal of Economic Studies, 51(1), 87-101. 
Khoo, E. (2018). Cover Story: Preserving the Old While Embracing the New. The Edge Markets. Retrieved fromhttps://www.theedgemarkets.com

MRT a Game Changer in Transforming Landscape of Country's Transportation: CEO (2017, July 16), The Sun Daily. Retrieved fromhttps://www.thesundaily.my

Ramele, R. B., \& Yamazaki, J. (2013). A Study on Traditional Javanese-Malay Kampung Structure, Culture and Community Activities in Kampung Sungai Haji Dorani, Selangor, Malaysia. Proceedings in the Asian Conference on Asian Studies, (pp. 6573).

Singh, V. P. (2013). Kajang and Its Surrounds: Glimpses from the Past. Kajang, Malaysia: Tanarata International Schools. ISBN 978-967-12347.

Supriharjo, R. D., Rahmawati, D., Santoso, E. B., Setiawan, R. P., \&Pradinie, K. (2016). Factors Influencing Community-Based Heritage Sustainability in Kampung Kemasan, Gresik. Procedia-Social and Behavioral Sciences, 227, 498-502.

Yeoh, T. (2011). The Many Sides of Good City Living. Penang Economic Monthly, 42-45.

Yu, H. H. (2017). Art, Making Cities: The Existence and Future of Urban Villages. 2017 BiCity Biennale of Urbanism. Yishu: Journal of Contemporary Chinese Art, 17(2), 4660. 